\title{
Castle and Cage: Meanings of Home for Palestinian Children and Families
}

\author{
Bree Akesson
}

Published online: 25 March 2014

(C) Springer International Publishing 2014

\begin{abstract}
Many children in Palestine live in an environment characterized by the constant threat of violence in their homes, schools, and neighborhood communities. It is within this context that an examination of the meaning of home is relevant. For home tends to represent a beloved and "safe" place for children in families in the context of political violence. Yet, as this paper illustrates, the meaning of home is much more complicated, and can be both positive and negative. Drawing from qualitative research with 18 families living in Palestine, home is first considered as a positive physical space, or a castle, for families affected by occupation and political violence. As a castle, home serves as (1) a site of family practices, (2) a center of identity, and (3) a place of protection. Secondly, this paper will conceptualize home as a cage for many of these same families, exploring (1) the unhealthy conditions that families live in, (2) the lack of privacy that characterizes many homes, and (3) the feeling that one is a prisoner within one's home. The paper ends by suggesting how practitioners and policymakers can better understand children and families multiple meanings of home in order to encourage the positive and mitigate the negative elements of home.
\end{abstract}

Keywords Children $\cdot$ Family $\cdot$ Palestine $\cdot$ Political violence . Home $\cdot$ Place

\footnotetext{
The research was supported in part by the Social Sciences and Humanities Research Council (SSHRC), the McGill University Faculty of Arts, and the Centre for research on Children and Families at McGill University. The author would also like to thank Elizabeth Fast and the anonymous peer reviewers for their helpful feedback.
}

B. Akesson $(\square)$

School of Social Work, McGill University, Wilson Hall, Room 300, 3506 University Street, Montréal, Québec H3A 2A7, Canada e-mail: bree.akesson@mail.mcgill.ca

\section{Introduction}

The theoretical concept of place is a useful point of departure for research with children and families, especially those who live in violent places and face the threat of being displaced. An examination of place as it relates to children is especially relevant, because place can represent a protective physical, social, and emotional environment where children can develop in safety and security (Jack 2008; Spencer 2005). For example, in times of uncertainty, families often work to create a stable home environment conducive for children to grow, survive, and thrive. However, certain environments can be hazardous, compromising their intended protective elements and making a particular locale an unsafe place.

This paper is one outcome from a larger research project examining the concept and meaning of place in the lives of children and families living in Palestine. ${ }^{1}$ The research depicted in this paper specifically examines the place of home, aiming to better understand the concept and meaning of home for children and families living under occupation and political violence. At the same time, the research also uncovers how and to what extent occupation and political violence affect their relationship with the home and how the home protects or does not protect children. For these children and families, the data suggest that home had contradictory elements of being both a castle and a cage, which will be explored in the following pages.

\footnotetext{
${ }^{1}$ The term "Palestine" (as opposed to "occupied Palestinian territories") reflects the recent actions of leading international organizations, such as the United Nations Security Council, the United Nations General Assembly, the European Union, the International Court of Justice, and the International Committee of the Red Cross.
} 


\section{The Multiple Meanings of Home}

Home is a familiar concept. People speak in terms of home all the time. Yet, this can be both an advantage and disadvantage for a sociological understanding of home; for everyone can participate in discussions about the meaning of home, while at the same time, everyone may claim to know the meaning and feeling of home based on their own personal understandings (Duyvendak 2011). Porteous and Smith (2001) discuss the multiple classification systems that scholars have used when struggling with the multiple meanings of home. Building upon Porteous and Smith's work, Duyvendak (2011) created the following typology of home: (1) familiarity, (2) haven, and (3) heaven. The first aspect of familiarity consists of knowing a place, a precondition for the next two features. Home as haven implies feelings of physical and material safety, security, predictability, and privacy relating to the microlevel of the home as a structure. Home as heaven is more outwardoriented and symbolic, helping individuals to develop a collective identity and to connect with others through shared history and the creation of intentional communities. Duyvendak (2011) concludes by explaining:

...whether experienced as haven or heaven, feeling at home is a highly selective emotion: we don't feel at home everywhere, or with everybody. Feeling at home seems to entail including some and excluding many (pp. 38-39).

Duyvendak's quote is especially relevant in the context of Palestine where both Palestinians and Israelis have historically tried to create and maintain home often at the expense of others not having a home.

Like any meaningful place, home can have diverse and contradictory meanings. The typology outlined by Duyvendak (2011) above indicates a positive understanding of home. But this paper suggests that there is another-albeit contradictory-element of place. On the one hand, Low (2004) speaks of home as a castle providing protection for the family. But, how stable is the home as a place? This is a serious question, not just in light of the Israeli occupation and its related violence, but also in light of the long-term changes in the meaning of home for Palestinian families who are reacting to everyday challenges such as poverty, unemployment, and family violence. Therefore, this paper suggests that home can also be considered a cage due to occupation and political violence. $^{2}$

\footnotetext{
${ }^{2}$ The term "occupation" is used in accordance with terminology of the United Nations and other international organizations. For this research, the term occupation describes the multilayered policies that Israel uses to control Palestinians including the actions of the Israeli police and army within West Bank and East Jerusalem and Israeli policies such as the permit system, checkpoints, and barriers.
}

\section{A History of the Occupation}

The West Bank and Gaza Strip have been occupied by Israel since 1967, marking the longest military occupation in modern history (Hajjar 2005). Since then, Israeli military occupation of Palestine has resulted in ongoing violence, with tens of thousands - both Israelis and Palestinians - injured or dead. As a response to the decades-long occupation, the first intifada erupted in 1987. The first intifada was largely characterized by Palestinian-driven nonviolent civil disobedience, including women, children, and the elderly, known as "the popular struggle". The first intifada ended in 1993 with the signing of the Oslo Accords between the Israeli government and the Palestinian Liberation Organization (PLO), which in 1994 was formally established as the Palestinian Authority (PA). Though at the time, the Accords were hailed as a means to establish Palestinian control over some of the West Bank, they actually further fragmented the West Bank (Jones 2012). According to Gordon (2008), the Oslo Accords outsourced the task of managing the Palestinian population to the PA, which was now responsible for the welfare of the maximum number of Palestinians in the least amount of area, whereas the least populated areas of the West Bank were left under direct Israeli control. The Accords resulted in the temporary division of the West Bank into three areas-referred to as areas A, B, and C-and additional areas annexed by Israel, effectively turning Palestine into a "swiss cheese" state (Krouzman 1999; Weizman 2007).

Several political and social conditions, such as the failure of the Oslo Accords to improve the lives of Palestinians and preparations from both Israel and Palestinian leaders to engage in violence, led to the beginning of the second intifada (or al-Aqsa intifada) in September 2000 (Pressman 2003). Compared to the first intifada, the second intifada was more devastating and marked by higher levels of violence perpetrated by both Israel and Palestine. Israeli forces repeatedly shelled and invaded Palestinian towns and cities, with urban warfare between the Israeli military and Palestinian civilians. Palestinian suicide bombers brought the violence into Israel with attacks on military and civilian sites (Araj 2012; Brym and Araj 2006; Moghadam 2003). The second intifada tapered off in $2005,{ }^{3}$ ending with approximately 4,000 Palestinians dead and more than 50,000 injured (B'Tselem 2013). According to the Institute for Counter-Terrorism (ICT) (n.d.), during the second intifada, 1,137 Israelis were killed, $78 \%$ of them civilians, and another 8,341 Israelis were injured.

Israeli Settlers Since the beginning of the occupation in 1967 , illegal Israeli settlements have been constructed throughout

\footnotetext{
${ }^{3}$ The ending date of the second intifada remains disputed, as there was no definitive event that effectively brought it to a close.
} 
Palestine in violation of international humanitarian law (Defence for Children International (DCI) 2010). Settlements are organized residential, industrial, and farming communities of Israeli civilians established on land in the occupied West Bank, including East Jerusalem, with the "approval and direct or indirect support of the Israeli government" (United Nations Office for the Coordination of Humanitarian Affairs (UNOCHA) 2007, p. 13). Settlements have a profound affect on Palestinian life. Apart from the loss of land taken for settlements, destruction of property is an everyday occurrence in the lives of Palestinians. Furthermore, there has been a sharp increase in Israeli-sanctioned demolitions of Palestinian homes, resulting in the displacement of Palestinian families (Save the Children UK (SCUK), Palestinian Counseling Centre, and Welfare Association 2009).

Violence in the Home Violence permeates the boundaries of Palestinian homes in a number of ways. Defence for Children International (DCI) (2012) recently reported that a majority of children arrested between January 2008 and January 2012 were arrested in their homes between midnight and $5 \mathrm{AM}$. In addition to forcibly entering homes to arrest children, families reported that, in the past, the Israeli army violently entered homes during large-scale incursions. Yet, violence in the home is not always the result of the occupation. In some cases, risk from the home may be revealed as the primary context for neglect, abuse, and/or violence against children. For example, in their study of the effects of political violence on Palestinian children, Garbarino and Kostelny (1996) reported significant risk to Palestinian children living in abusive families. Likewise, in her study of family functioning in Palestine, Khamis (2000) found that $16 \%$ of Palestinian households showed rates of maltreatment indicative of psychological abuse. In war-affected Afghanistan, following the Taliban's defeat, research indicated that significant numbers of poor families arranged marriages for their daughters as young as 11 years old, often to men in their 50s (Wessells and Kostelny 2004). And more recent research in Afghanistan found that violence in the home was more of a critical predictor of children's negative mental health than the extraordinary levels of violence outside of the home (Panter-Brick, Goodman, Tol, and Eggerman 2011). These findings reflect the family-level violence, often related to both structural and collective violence, that children may face on a daily basis. In these cases, the home can be considered as more of a "cage" than a "castle". It is within this complicated context of Israeli settlements, home demolitions, and violence in the home that an examination of the meaning of home is relevant. For home tends to represent a beloved and "safe" place for children in families in the context of political violence. Yet, as this paper illustrates, the meaning of home is much more complicated.

\section{Methodology}

Due to the difficulties of collecting data in unstable settings, research on children affected by political violence tends to use research methodologies that employ cross-sectional surveys of school-aged children. Although this type of research still adds to a growing knowledge base, it limits a more comprehensive understanding of the experience of children in these contexts. Therefore, there is a need for studies that use creative methods to collect data about multiple perspectives from diverse sources. The methodology for this study took a qualitative approach — specifically rapid ethnography for data collection and grounded theory for analysis - designed to answer the overarching research question, effectively engaged family members of all ages, and used place-based methods to reflect the research's theoretical commitment to explore the concept and meaning of place.

\section{Participant Selection}

Community gatekeepers helped build trust and acceptance between the research team and the Palestinian communities, thus enabling access to and recruitment of families for the study. However, if gatekeepers are well-known and/or hold positions of power within the same ethnocultural group, then participants' responses may be impacted (Edwards 1998; Murray and Wynne 2001). Therefore, a range of gatekeepers in each sampling site were engaged in order to minimize the potential bias that might have resulted from being associated with one individual or organization. These gatekeepers represented nongovernmental and community-based organizations, UN organizations, and community members.

With the assistance of these gatekeepers, primary data collection was conducted in 2012, with convenience and snowball sampling of three Palestinian families from six different administrative regions of the occupied West Bank (areas A, B, C, H1, and H2) and annexed East Jerusalem (EJ), for a total of 18 families (see Table 1).

Sampling from multiple sites and in various settings (refugee camp, village, city, and encampment) under a range of territorial control (Israeli and/or Palestinian) provided diverse examples of how Palestinian children and their families interpret, understand, and navigate their home environments.

A minimum of three family members (adult caregiver, older child (aged 9-18), and younger child (8 and under)) from each family were invited to participate in a collaborative family interview to understand their experience with place while living under occupation. Collaborative family interviews often included members of the larger extended family, or hamula, with some interviews including up to 12 family members. 
Table 1 Site selection

\begin{tabular}{|c|c|c|c|c|c|c|c|}
\hline Area & Site (code) & Site type & Security control by ${ }^{\mathrm{a}}$ & Civilian control by ${ }^{\mathrm{b}}$ & $\begin{array}{l}\text { Area } \\
\left(\mathrm{km}^{2}\right)\end{array}$ & $\begin{array}{l}\text { Palestinian } \\
\text { population }\end{array}$ & $\begin{array}{l}\text { Number of } \\
\text { participants } \\
\text { (adult/children) }\end{array}$ \\
\hline A & Balata (BA) & Refugee camp & Palestinian & Palestinian & 1 & 30,000 & $25(4 / 21)$ \\
\hline B & Al-Makkah (VI) & Village & Israeli & Palestinian & 2 & 1,000 & $30(11 / 19)$ \\
\hline $\mathrm{C}$ & Al-Jazari (BE) & Bedouin encampment & Israeli & Israeli & 5 & 100 & $26(6 / 20)$ \\
\hline $\mathrm{C}$ & East Jerusalem (EJ) & City & Israeli & Israeli & $6.4-7$ & 260,800 & $15(9 / 6)$ \\
\hline H1 & Hebron City (H1) & City & Palestinian & Palestinian & 18 & 140,000 & $26(11 / 15)$ \\
\hline $\mathrm{H} 2$ & Hebron City (H2) & City & Israeli & Israeli & 4.5 & 30,000 & $27(9 / 18)$ \\
\hline Total & & & & & & & $149(50 / 99)$ \\
\hline
\end{tabular}

NB: Three family interviews were conducted at each site

${ }^{a}$ Refers to who has control over security, such as police forces

${ }^{\mathrm{b}}$ Refers to who has control over civilian affairs, such as schools and businesses

Basic demographics - gender, age, education, and employment-were collected from each family member and used to develop a brief family summary used in subsequent data analysis. Table 2 shows the distribution of the study sample, according to age and gender. Eighteen families were interviewed, with a total of 149 individual family members (48\% male and $52 \%$ female) - 50 adults and 99 children. There were 103 family members who were from the primary index family ( $\left.a^{\prime} i l a\right)$ and 46 family members who were part of the extended family (hamula).

Table 3 presents the distribution of the index families within the study sample, according to education and employment. In 9 out of 18 households, one or more parent had completed tarjehe (secondary school). Eleven out of 18 households had one or more parent who was employed outside the home; in six of 18 households, both parents were unemployed. Four out of 18 households had index school-age children who were not attending school, with a total of eight index children not currently enrolled in school at the time of the interview ( $10 \%$ of total index children).

In addition to collaborative family interviews, ten key informant interviews were conducted with local and

Table 2 Family demographics (age and gender)

\begin{tabular}{llllll}
\hline & Index family $\left(a^{\prime} \text { ila }\right)^{\mathrm{a}}$ & \multicolumn{2}{l}{ Other family $\left(\right.$ hamula $^{\mathrm{b}}$} & Total \\
\hline Adults (18+) & Male (father) & 9 & Male & 8 & 17 \\
& Female (mother) & 16 & Female & 17 & 33 \\
& & 25 & & 25 & 50 \\
\multirow{5}{*}{ Children (<18) } & Male & 45 & Male & 10 & 55 \\
& Female & 33 & Female & 11 & 44 \\
\multirow{2}{*}{ Total } & 78 & & 21 & 99 \\
& & 103 & & 46 & 149 \\
\hline
\end{tabular}

${ }^{\text {a } I m m e d i a t e, ~ n u c l e a r ~ f a m i l y ~}$

${ }^{\mathrm{b}}$ Extended family international nongovernmental organization (NGO) personnel and community leaders who work with children and families in Palestine. Key informants were selected through theoretical sampling. Key informant interviews resulted in the validation of data from other sources and discovery of information not revealed in collaborative family interviews.

\section{Procedure and Measures}

Rapid Ethnography The methods were primarily qualitative in nature using rapid ethnography for the data collection process (Mignone et al. 2009). The aim of conventional ethnography is to describe a specific society or culture and to understand the world and the benefits and practices of participants through their own eyes (an emic approach) without the imposition of outsider assumptions in order to understand participants' ways of living. Rapid ethnography starts with the same assumptions about culture as conventional ethnography, with participants selected for their unique cultural perspective and expertise (Handwerker 2001). This method provides a reasonable understanding of the research participants and their activities given significant time pressures and limited time in the field (Millen 2000). Rapid ethnography differs from conventional ethnography in that the researcher enters to cultural system with a specific data plan, identified informants, and specific timelines, because the researcher already has some familiarity with the issue and context (Handwerker 2001). The core elements of rapid ethnography that were included in this particular study included a tight focus on children and place, the use of key informants, the capture of rich data through interactive observation techniques, and multiple data gathering techniques (e.g., narrative, drawing, and mapmaking) to increase the likelihood of discovering new concepts and quickly triangulating data (Millen 2000). 
Table 3 Family demographics (education and employment)

\begin{tabular}{|c|c|c|c|c|c|}
\hline & \multicolumn{2}{|c|}{ Completed Tarjehe $e^{\mathrm{a}}$} & \multicolumn{2}{|c|}{ Employed outside home } & \multirow[t]{2}{*}{ Index school-age children in school? } \\
\hline & Father & Mother & Father & Mother & \\
\hline Yes & 4 & 7 & 9 & 3 & 70 \\
\hline No & 14 & 12 & 9 & 16 & 8 \\
\hline Total & 18 & $19^{\mathrm{b}}$ & 18 & 19 & 78 \\
\hline
\end{tabular}

${ }^{\mathrm{a}}$ Secondary school

${ }^{\mathrm{b}}$ Some index families had more than one mother

Participant Observation The researcher's in-depth observations of physical activities and social and material contexts were included as data during 3 months of fieldwork in the West Bank and East Jerusalem between 2010 and 2012. Participant observation consisted of visual observations and experiences, informal and formal discussions, and interactions with children, families, and communities. Written records were created in vivo, and elaborated upon as daily analytic memos (both written and audio recorded for later transcription). Analytic memos reflected on the main concepts, themes, issues, and questions that were encountered during the research process.

Interviews After obtaining full and informed consent from each family member, collaborative family interviews were conducted and lasted between 1 and $2 \mathrm{~h}^{4}{ }^{4}$ Sixteen of the 18 family interviews were conducted in the family's home. Participants were assured that all information would remain confidential and used only for research purposes. Sixteen of the 18 family interviews were conducted primarily in Arabic. ${ }^{5}$ Eight of ten key informant interviews were conducted primarily in English. With the participants' permission, interviews were audiotaped and subsequently transcribed by an Arabicspeaking research assistant. All but two families agreed to be audiotaped, and two additional families asked for the audiorecording to be stopped for portions of the interview when sharing especially sensitive material.

Participants were not paid for their participation in the study. All children who participated in the study were given a sticker of their choice at the beginning of the family interview. Materials used for the drawing and mapmaking - pens, pencils, markers, and paper - were given to each family at the end of the interview. Finally, each family was given a box of candy as a token of appreciation for their participation.

\footnotetext{
$\overline{{ }^{4} \text { Approval for }}$ research with human participants was obtained through McGill University's Research Ethics Board prior to commencement of the study.

${ }^{5}$ Some interviews switched between English and Arabic, depending on which family member was speaking and what language they preferred.
}

Interview Guide The interview guide was piloted in 2010 during one-on-one interviews with Palestinian youth who grew up in the West Bank and were currently living in a large North American city. The piloting of the interview guide, as well as the pilot study findings, shaped the interview guide that was used with families and key informants during primary data collection in West Bank and East Jerusalem in 2012.

The interview was divided into three parts. In addition to building rapport and trust, guiding questions in part 1 of the interview focused on getting to know the participants and their history of living in a particular place. Also included in part 1 were questions about basic demographics (e.g., names, ages, education, etc.) for descriptive statistics (see Tables 2 and 3 above). Part 2 of the interview concentrated on describing daily life in relation to place, as well as the effects of everyday occupation and violence. Participants were asked to describe their homes and neighborhood communities, a typical day in this place, and how they get to and from different places. Part 2 specifically addressed the concept and meaning of home by asking family members questions such as "What does the word home mean to you?" and "What would happen if your home was destroyed or you were forced to leave it?" Part 3 of the interview revolved around how different family members support and protect each other in different settings. The interview concluded with an opportunity for all family members to add anything to the interview and to ask questions about the research and researcher.

Drawing and Mapmaking According to Dennis, Gaulocher, Carpiano, and Brown (2009), collecting data from the widest variety of sources and using the widest variety of methods produces the most complete picture of participants' experience, especially when researching place:

We contend that everyday knowledge of social places is a nexus of locational, visual, and narrative forms of knowledge. In other words, people's lived experiences consist of cognition of location, remembered images, and storied accounts of events (pp. 467-468). 
In this way, research participants can indicate where experiences occurred (through maps), what experiences looked like (through drawings), and how experiences unfolded (through narrative). Combining maps, narratives, and drawings ensures that participants' experiences are not reduced to one aspect, and contributes to an understanding of how they interpret, understand, and navigate their environments.

The methodology for this study encouraged all family members - both children and adults - to draw during the collaborative family interview in order to illustrate a point or tell a story. Children were specifically asked to produce at least three drawings (though they often drew many more): (1) a free drawing or a drawing of anything they wanted to draw; (2) a neighborhood map, showing the important places in their community; and (3) a dream place, where they would like to go one day. Drawing and mapmaking are ways to gain the participation of children in an effective and meaningful way. Furthermore, these tools create an environment where children may feel more at ease, where they are able to express themselves, and where they do not feel at risk of giving a "wrong" answer in a research context. Through visual depiction, these multiple dimensions of place ultimately provided a more holistic understanding of the Palestinian relationship with place in the context of occupation and political violence.

\section{Data Analysis}

Data collection resulted in a large data load including: over 100 pages of typed field notes, approximately 300 pages of typed transcript pages from 18 collaborative family interviews, 150 typed transcript pages from 10 key informant interviews, 200 drawings and maps, and 500 photos and videos. This section describes the methods used to analyze this large amount of data.

Translation and Transcription Two research assistants translated and transcribed all Arabic interview data that were audiorecorded. The author transcribed all English interviews. Upon completion of the first interview transcript, the author listened to the audio recording in order to check for errors and ask clarifying questions of the transcribing research assistant. The amended version of the transcript was returned to the research assistant who listened to the recording again and made additional changes and comments, after which the author reviewed and finalized the transcript.

Grounded Theory Analysis Grounded theory was chosen for data analysis because of its systematic, yet flexible guidelines, which suited the volatile research setting. As suggested by
Charmaz (2006), data was analyzed early in the data collection process by separating, sorting, and synthesizing through qualitative coding. Dedoose - a web-based platform for qualitative data analysis - was used to facilitate coding and analysis of data. Analysis of the data involved careful reading and annotation of the collated information so as to ascertain the meaning and significance that participants attributed to their experiences. The following data analysis steps were followed: (1) As soon as the transcript was finalized, the transcripts were read in order to get a general sense of the interview. Field notes, drawings, maps, and photos were also closely examined to identify salient themes. (2) Natural meaning units - or portions of the text that were related to an identifiable theme-were highlighted and coded in Dedoose. (3) Using constant comparison method (Glaser and Strauss 1967; Maykut and Morehouse 1994), these lists were further combined and categorized by merging any overlapping ideas. (4) The final four themes were grouped around important places that children and families interacted with in Palestine: home, school, neighborhood community, and nation-state. This paper investigates the first theme, discussing how home can be both a castle and a cage for Palestinian children and families.

\section{Findings}

Findings indicated an inherent contradiction in the concept and meaning of home for Palestinian children and families. Participants expressed a tension between home as both a castle and a cage. Home is a castle in that it represents a place for the family, a center for individual and collective identity, and offers a layer of protection for children and families in the context of political violence. However, the home can serve as a cage for family members who are not allowed to or choose not to go outside the home for fear of being exposed to the violence in the surrounding environment. This section first considers home as a positive physical space, or a castle, for families. As a castle, home serves as (1) a site of family practices, (2) a center of identity, and (3) a place of protection in the context of occupation and political violence. Then, turning to the contradiction that home poses, the paper conceptualizes home as a cage, exploring (1) the unhealthy conditions that some families live in, (2) the lack of privacy that characterizes many families' homes, and (3) the feeling that one is a prisoner in one's own home.

\section{Home as Castle}

Home as Family Home is the quintessential family space, with family and home closely intertwined. Research participants routinely spoke about their families in relation to home 
spaces and even equated home with family. This implies that home may be more socially than territorially defined. Therefore, home's meaning is established around particular familiar people and includes the people one interacts with (Duyvendak 2011; Nowicka 2007). Home then becomes an inclusive and distinct place where people have strong social, psychological, and emotional attachments (Duyvendak 2011; Easthope 2004). The connection between people and place is not new. According to Mumford (1961), "people are as attached to places as they are attached to families and friends. When these loyalties come together, one then has the most tenacious cement possible for human society" (p. 287).

If, as Relph (1993) asserts, place is "a territory of meanings" (p. 36), then people are an important vehicle for this meaning-making process. Therefore, it was not surprising that many family members equated home with family. This was especially true within this context of Palestinian family life. When speaking about her home, 26-year-old Sanaa explained: "Like any human being, when he comes home, he finds his father and his mother and his children. It's the family. It's something that you cannot trade for anything" (EJ3). For Sanaa, home felt like family, with familiarity being an element of belonging to this particular place. Similarly, Abu-Karim explained, "The home, as a land, is my father and my mother, my parents, both" (BE2). ${ }^{6}$ AbuKarim indicated that home represents a physical place, as well as the family.

Twenty-four-year-old Amina moved from her childhood home in East Jerusalem to al-Adib (in the West Bank) when she married her husband. But when she visited her childhood home in East Jerusalem, she expected to find familiar and important people, such as her parents and siblings:

Amina: And even now, I live in al-Adib and my family [lives] in [East Jerusalem]. But I don't feel like my home is in al-Adib, because my family is not there...

Interviewer: So where do you see home if home is not al-Adib?

Amina: Here. The house of my parents (EJ3).

Amina's words indicated that home is formed out of numerous social relationships stretched over time and space, changing in relation to the movements of the family. She also emphasized the value of the hamula in contributing to a sense of familiarity and comfort.

Home as Center of Identity Organized by Lloyd, Patton, \& Cammack (1996), place can be structured by a hierarchy of home, neighborhood, city, region, and country. Yet home

\footnotetext{
${ }^{6}$ In Arabic culture, after the birth of the first child, parents are given the honorary title of $a b u$ (father of) and umm (mother of), followed by the name of the first-born son. These identifiers are used throughout this paper to indicate fathers and mothers from the index families.
}

often remains at the center of the hierarchy. The home is a central physical and spatial location for people's social and emotional lives (Christensen and O'Brien 2003) and a place where one's identity develops. It is the key context for the family, where children are centered within the family, often nested in bonds of love and care, with parents serving as gatekeepers for children's well-being.

Like the concept of home as family, home as a center creates opportunities for maintaining social ties and relationships and maintains elements of one's identity as represented by connection to place. The centrality of home in the lives of Palestinian children could be visualized through their drawings, where home was frequently depicted. Often, the home was situated in the center of the paper-a starting point for the drawing in general - with other elements of place surrounding the home, such as flowers (H23), water cisterns (H22), and cars (VI1). Even children who had never drawn before started their drawings with the square outline of the home (BE1). This indicates that the home is something they are familiar with and a central place in their lives.

For some children, their current home was positively depicted as a dream place. For example, when asked to draw her dream place, 9-year-old Nafissa drew her current home, a tent in the middle of a Bedouin encampment. Using the drawing, Nafissa carefully described all of the familiar elements that made it a special place for her:

Nafissa: ...this [is] our house.... Here is a drawer, a carburetor [generator] and a TV and a heart.

Interviewer: It's the tent [here]?

Nafissa: Yes.

Interviewer: And what is this?

Nafissa: Heart.

Interviewer: A heart, yes. It's beautiful, and what does

this say?

Nafissa: The home of [my father] Abu-Karim (BE2).

As Nafissa's words illustrate, it is not just the foundation, four walls and roof of the home, but all it contains: a drawer, where the family keeps precious items, a generator, which provides electricity to the family, and the TV, where the family gathers in the evening. These familiar objects symbolize the practices that the family engages in and which contribute to children's wellbeing. Douglas (1991) argues that homes structure time and memory through their capacity to order family practices spatially, for example, through such activities as communal eating, chores, religious observances, and the distribution of resources. These family practices take place within the physical space of the house, which is, in time, transformed into a home, the place where individual and collective identities are worked on (Birdwell-Pheasant and Lawrence-Zúñiga 1999). Therefore, as a place of family centeredness, home confers a sense of identity upon those living within it. 
In addition to being a central and physical place, some participants described home as having an emotional role. For example, Umm-Omar, a 30-year-old mother of three from the village of Al-Makkah, explained what the word home meant to her: "My life. As a physical structure, it's my life. As a word, home is the blood that goes through my body" (VI2). Fatima, a 25-year-old mother of one from the same village said that home is "the most precious thing to us" (VI1). AbuKarim explained the difference between the physical home and the emotional home: "The house, even if it's built from wood or stones or ... gold, it is home. It is this home" (BE2). In East Jerusalem, Abu-Rachid elaborated upon this idea of home as more than just a physical structure:

The house is not stone. It is not like a rented house. The house is a memory. It is a thing I don't know, I can't explain it, but I feel very related to this house. Even if I had a villa in any place else, I will stay here. I am much happier than anyplace else in the world. I am so close to this house and this neighborhood (EJ2).

Even though his home is located in a violent neighborhood within East Jerusalem, Abu-Rachid still feels emotionally connected to this place, illustrating the strong connection that Palestinians have to their homes and neighborhood communities.

In addition to being a vital component of one's life on both a physical and emotional level, some participants connected the home to their individual futures and the future of the family. For many families, home is a place where the family's children grow up and then start their own family, indicating that the home is important for the continuation of generations. Abu-Rachid explained:

I was born in that house. My children were born in that house. And I hope they will, or have their children in this house. That is at least what I am trying to do. (EJ2).

Thirteen-year-old Basma explained: "[Home is] my life. I love the gathering of the whole family. Yes, the gathering. And we live a good life. I hope to raise my [future] dreams here" (VI2). Basma's quote touches upon home as "everything", as well as an important place for her future. She also alludes to home as a place where one can gather with the family. The importance of gathering together - in times of both peace and insecuritywas reflected in participants' conceptualizations of home as a gathering place. According to Brannen and O’Brien (1996), home is a key site for establishing a sense of belonging. The home and family are sites where children learn the concept of togetherness regardless of material, ideological, and emotional conditions (Douglas 1991). Umm-Imed, explained: "Being in my home means stability for me and being with my children, gathering, living with my family" (VI3). The act of gathering together has direct implications for protecting children. And, as the next section describes, in contexts of violence, children and families noted that gathering was one of the most important ways to stay safe.

Home as Protective In many societies, including Palestinian, the family has primary responsibility for their children on behalf of the wider community structure (Parton 2006). In fact, the family's influence on Palestinian life can be seen in its housing patterns, through which they seek some form of collective security (Ghabra 1988). In areas affected by political violence, one way of protecting children is to ensure that they stay within the home or within their local neighborhood. In this way, home can serve as a place of refuge, shelter, and security (Allan and Crow 1989; Porteous and Smith 2001). Many families indicated that the purpose of the home is to keep family members - especially the younger children - safe. In East Jerusalem, Umm-Ayoub and her 26year-old daughter both described their home as a place that is safe (EJ3). In particular, families noted that home provides safety for children. Umm-Mourad, also from East Jerusalem, elaborated on how the home protects children:

It's your home. You can close the door whenever you want. You can sit with the children. You can take care of them. There is a safety feeling (EJ1).

This "safety feeling" was reiterated throughout many of the collaborative family interviews, as parents and children both expressed that home was usually a physically safe place, especially in the context of political violence.

The home also serves as a haven where the family can ensure their children's growth and development. Caregivers can ensure that children are safe and protected, provided with comfort and care, and safeguarded in their health and wellbeing. When Umm-Mourad was asked how she protects her children, she replied, "The home is the safest place. If I have home, then I can protect my children...even if we don't own it" (EJ1). Like Umm-Mourad, some families distinguished between living in a home that they owned and renting a home. However, for them, the role of home was the same whether or not they owned the home. For others, home had a feeling of impermanence and instability if they were renting the home. But the home - whether permanent or not —overwhelmingly represented a means of protection.

As the above examples show, home operates as a metaphor for (1) family, (2) centeredness, and (3) protection. Home does not just represent the place where one lives, but it symbolizes the care, support, and commonalities that a Palestinian family living close to each other share in the same geographically defined space. Nevertheless, as much as home can be a castle, it can also be a contradiction. For example, home can become a cage, which is discussed in the following section. 


\section{Home as Cage}

The phenomenology of home tends to emphasize positive elements such as familiarity, order, permanency, comfort, and culture (Duyvendak 2011). From this perspective, home is fixed, rooted, and impervious to change. However, while home is often conceived of as a safe haven, it can also be an unstable and overburdened place. An example of the contradictory role of home comes from the migration research of Ahmed (1999), who views home as both familiar and/or strange. Ahmed's idea can be extended to describe home as both castle and cage. This section will further explore the second and more negative element of home, specifically home as (1) unhealthy, (2) not private, and (3) a prison.

Home as Unhealthy As discussed in the previous section, the built structure of the home is often conceptualized as a safe shelter for children and family providing protection from outside elements. However, for many families, their homes posed a range of environmental risk factors - both related and unrelated to the occupation - that directly affected the health of family members. This idea was suggested by several families who, in the following quotes, explained that their homes were not healthy places:

My children [are] always sick [from] the moisture that gets into our home here. We just have two rooms (points to them). The reservoir room (where they keep the house supplies, such as flour, legumes, sugar and salt), my children sleep there. Inside it is the flour and oven. There is no space here. See here how we close the roof because of rain (shows how they cover the roof with a piece of steel or wood). Rain comes over here. It's not healthy at all (BA3).

Houses are close to each other. See the wall, it is common between us and our neighbors. And, in this room there is no window. So two rooms without ventilation.... If I go outside, my eyes will hurt me, because I'm not used to sun and healthy air. I don't see sun everyday. If I want to hang laundry, I should go to the sixth floor just to find the sun (BA3).

Children expressed similar feelings about their homes being unhealthy places, as in this exchange between siblings-14-year-old Anissa, 12-year-old Mahfoud, and 10year-old Anise-and their mother, Umm-Mahfoud in Balata:

Anissa: It is not nice. There is no sun getting through. Mahfoud: There is no place to play inside. Umm-Mahfoud: They are stressed out in this home. Anise: There is no place to play around (BA3).
The theme that there are no places to play was also reiterated when children spoke about their neighborhood communities.

Seven-year-old Nadir from Hebron drew a picture of his home and described the important elements of home as "sun, stairs, home, and light" (H12). After he finished explaining his drawing, Nadir's father, Abu-Ali, revealed the bullet holes in the home's roof where rainwater dripped in and made the home damp and cold in the winter and explained:

When it rained this year, there was leaking. We weren't able to control the leaking. We were trying to put bottles to protect our house, trying our best to remove the big amount of water. It is not like, healthy, this home (H12).

Drawings of dream places served as catalysts for many children to compare their dreams to the reality of their unhealthy homes. Twelve-year-old Samira drew her dream place and explained:

Samira: You see, this house (indicating her current home), it is not a healthy house, not in the winter and not in the summer. So this house (showing her drawing) is my dream place, because it is a healthy place to live. Interviewer: What is healthy about it? Samira: Because the sun is coming in. Interviewer: I can see the sun [in the drawing]. And here (indicating Samira's current home), you cannot see the sun?

Samira: In this section, yes (pointing outside), but inside, no (EJ3).

Sunlight, windows, and air were named as elements of a healthy living environment by both children and adults.

Another element that made a home feel like a cage is the fact that many Palestinian families are unable to repair, develop, or expand their homes. Obtaining permits to build on their own land is nearly impossible as $94 \%$ of building permit requests submitted by Palestinians are denied by Israeli authorities (Epshtain 2012). The Wadi Hilweh Information Center-Silwan (2013) recently described a family in East Jerusalem who was ordered by an Israeli court to remove tin plates from their home's roof or else they would be forcibly evacuated. The family installed the tin plates about 20 years ago to protect their home from rain. By removing the tin plates from their roof, the home became exposed to potentially dangerous and corrosive environmental elements (sun, rain, and wind) and the family loses the protection that a roof offers.

Perhaps most damaging was a feeling of not being able to develop their own home in a way that corresponds with the family's changing needs. For example, many families expressed frustration at not being able to renovate their homes leading to a crowded and cramped living situation for family members. Umm-Malik, her 26-year-old son, Malik, and his 
25-year-old wife Fatima, explained the difficulty in expanding the home to accommodate their growing family:

Umm-Malik: There is no space. We have no other places to go.

Fatima: And she has another [child] who is getting married too, but there is no space. All people need to be building, but, you know, under Israeli occupation, you can't do anything.

Malik: See, we can't do anything.

Umm-Malik: And al Yehud (the Jews) took our lands, so we can't build (VI1). ${ }^{7}$

When the family continues to grow, yet physical expansion is not allowed, there is not enough space to live well in place. The family's growth becomes stunted, forcing some family members to move away from the a'ila and hamula, thereby breaking up strong family ties that can protect children and families.

Furthermore, research has shown that the effects of the physical environment - noise level, overcrowding, and housing and neighborhood quality - are as significant for children's development as psychosocial characteristics such as relationships with parents and peers (Evans and Hygge 2007; Evans and Lepore 1993; Evans 2006). Developmental outcomes as a result of crowded home environments include children's withdrawal behavior as a means of coping, parental unresponsiveness, strains on parent-child relationships, higher levels of psychological distress, higher levels of behavior difficulties in school, declines in motivational behavior, and a level of learned helplessness. The implications of this are relevant to the Palestinian context, especially when considering the added impact of war-related violence. For example, some children expressed that their crowded homes made focusing on schoolwork difficult, and as a consequence, their grades suffered.

Even if families were lucky enough to obtain a permit, poverty posed an additional obstacle. Family interviews were often conducted in poorly constructed homes or homes that had been damaged in the course of the occupation that did not provide this physical protection for children and their families. When families were asked about the condition of the home, they often replied that they were too poor to make improvements on deteriorating homes. Nevertheless, while families noted the home's shortcomings and dangerous environmental conditions, children and families continued to acknowledge the importance of home, thus reaffirming home as both a castle and a cage.

\footnotetext{
${ }_{7}$ Al Isra'iliyin is the Arabic word for "Israelis", yet it is cumbersome in colloquial speech. Therefore, many Palestinians, especially those from smaller villages, often refer to Israelis as al Yehud ("the Jews") although they tend to translate it to English as "the Jewish" or simply jeish ("army").
}

Home as not Private According to Lang (1987), when people's social needs are balanced by the individual autonomy that comes with privacy, social interactions occur more easily. Ambiguous space - such as those that are neither public nor private - tends to prohibit positive social exchanges, because the individual is less able to control the interaction on his or her terms. Therefore, privacy is important for one to engage in positive social interactions with others and, as an extension, it is essential for well-being. For children, privacy is fundamental for positive psychological well-being. In her description of ideal spaces for infants and toddlers, Olds (1987) explains that spaces that provide privacy are essential for younger children's development of self-concept and personal identity. Clark's (2004) research exploring experiences of place with children 3 to 4 years old found that they valued places with a degree of privacy where they had the ability to regulate social interaction. Clark's research finding is in alignment with the assertion that children's physical spaces should balance both social contact and the possibility of privacy (Altman 1975; David and Weinstein 1987; Wolfe 1978). According to Lang (1987), the development of privacy is part of a socialization process. As children grow, they need more privacy (Guardo 1969; Meisels and Guardo 1969), correlating with the child's growth and maturity. But what happens when occupation and political violence encroaches upon one's sense of privacy?

In her research with Palestinians in Lebanon, Peteet (2005) describes the Palestinian refugee camps as liminal spaces, vacillating between private and public spheres. This description provides an opening within which to explore privacy as a sociospatial issue for Palestinian children and families. Today's Palestinian refugee families live on the original tiny spaces of land that were provided to them by United Nations Relief and Works Agency for Palestine Refugees in the Near East (UNRWA) when Palestinians were first displaced in 1948. Yet, as the family grows, the domestic space can only grow vertically in a haphazardly and piece-meal fashion, taking the form of a multistoried structure, with extended family living on additional floors. Harker (2011) observes: "This shift from horizontal to vertical living offers a cheaper means of construction, since residents can build on land that is already owned without the need to buy more" (p. 5). These vertical family places annex each other, with very little space in between. Therefore, one family's window oftentimes looks directly into another family's home.

Families noted how the layout of space challenged access to privacy within the home. Umm-Mourad explained her living situation when she was forcibly evicted from her home in East Jerusalem and moved her family into a relative's home in the West Bank: "So, it is not my house, and the children don't live free. They don't have their own rooms. They can't study well. They can't play" (EJ1). Privacy was a concern for children as well as parents. Sixteen-year-old Wided drew her 
dream place - a room of her own. The left side of the drawing has a desk and computer situated underneath an open window with curtains, while the right side of the drawing includes a bed, nightstand, and table lamp. Wided explained her drawing: "I dream about a room...just for me. It has a window in it, and it is just for me" (EJ3).

Indeed, privacy needs are very much a part of culture (Altman and Chemers 1980; Lang 1987). The organization of a family home - how rooms are designated a function, where items are kept—reflects family members' culturally-based attitudes towards privacy (Brolin 1976; Lang 1987; Porteous 1976; Rapoport 1969). How the built environment is laid out depends on how individuals relate to each other in space, thereby varying considerably by culture. There are major cultural differences in the types of privacy sought by individuals (Rapoport 1969), reflected in both the internal and external organization of the home. Therefore, Wided's description of her dream place as "a room just for me" challenges ideas that collectivist societies don't want, need, or value privacy.

The ongoing tactics of the Israeli occupation also exemplifies an involuntary concession of the privacy of Palestinian families. "Walking through walls" is a military tactic first implemented during the 2002 invasion of Nablus, when soldiers broke through the walls of Palestinian homes in order to avoid the streets, roads, alleys, and courtyards, where they feared being attacked by Palestinian fighters (Bleibleh 2010; Weizman 2007). The "penetration of war into the private domain of the home" is described by Weizman (2007) as "the most profound form of trauma and humiliation” (p. 194) for Palestinian families. In interviews, families in Balata refugee camp described the tactic of "walking through walls". For example, halfway through a family interview, Umm-Mahfoud and her 14-year-old daughter Anissa revealed a small room filled with hanging laundry and sleeping mats stacked on top of one another, where the children slept. On the eastern wall of this room was a large square-shaped area that was plastered over with cement. Umm-Mahfoud explained that several years ago, the Israeli army entered her home, then cut through this wall to get to her neighbor's home, where they were searching for a wanted man.

It was as if they knew everything about our house before they came. They had dogs and other equipment to enter. They asked my husband to help them [cut through the wall]. [But], he was sick with back pain, so he couldn't. [So,] they were mad and brutal. ... Four of my children were sleeping here. We were awake, because it wasn't in the middle of the night. ...they entered and they knew that we have one wall between us and our neighbor. They know there is something here, and it's the only way to go through the neighbor (BA3).
A survey conducted after the 2002 invasion of Nablus showed more than half of the buildings had routes forced through them, with between one to eight openings in their walls, floors, and ceilings (Abujidi 2005). Israeli soldiers reported that they spent the entire time during the invasion inside Palestinian families' homes, which they transformed into sleeping quarters, prisons, and even parking garages (Weizman 2007). Families were often locked in one room, where they were forced to remain-sometimes for several days - until the military operation concluded, often without water, food, or sanitation (Baltzer 2007). By "walking through walls", families described how private homes became spaces of warfare and occupation, in stark contrast to the safe domestic spaces of the home for children and their families. Conversely, these private spaces became safe spaces for soldiers, who avoided what they perceived as dangerous and deadly public spaces (Bleibleh 2010).

The privacy of Palestinian communities continues to be compromised in today's post-second intifada era. According to Weizman (2007), the IDF completed three-dimensional models of the entire West Bank and Gaza Strip, providing intricate details of family homes including locations of doors and windows and layouts of rooms. In this discussion about the importance of privacy in the lives of Palestinian children and families, the home is not just a physical demarcation between inside and outside, but it becomes an important metaphor in the construction of the private and the public.

Home as Prison As the previous section shows, the home cannot be thought of in static terms. Home must be viewed through its relation to family practices (Morgan 1996, 1999) and movements (Christensen, James, and Jenks 2000). Children use home as a center of activity, from which all other activity springs from. These movements are consistently moderated by caregivers, as well as the context of violence within which children may be living in. Families engage in multiple place-related practices revolving around the home in order to protect their children including forcing children to stay at home, gathering together in the home when there is an upsurge in violence, and restricting children from accessing certain places outside of the home. Although intended as a means of protection, restricting children's access to places beyond the home can lead to the feeling that the home is a prison, a comment from many of the research participants, especially those living in more violent places.

Settler harassment was widespread throughout all six research sites. Israeli settlers created an atmosphere where many Palestinian families did not feel safe to leave their homes, thereby trapping them inside. Families described instances of settlers forcibly entering their homes, throwing stones at windows, and attacking Palestinian children and adults on the streets. According to the European Union (as cited in Hider 2012), settler violence has more than tripled in the 3 years 
leading up to 2011. Because of this violence, children and parents do not want to leave their homes. Abu-Majd from Hebron explained, "Our children are used to living like anyone who is in prison. You see our house is covered with these bars?" He asked his 7-year-old niece, Wafa, to pull back the curtains covering the bars on the windows. "Because al Yehud (the Jews) attack us and harass us," Abu-Majd said while pointing to the settlements across the street (H21). Families in more volatile places, such as East Jerusalem and Hebron, explained how they did not want to leave their homes - even to go on a brief errand to the corner store-because they were afraid settlers would take over their home when they were gone. Even if settlers do not physically occupy one's home, they can use the Israeli courts to evict Palestinians from their homes. Twenty-three-year-old Sanaa explained how her family refused to leave their home when faced with an eviction order:

And actually, my uncle and my dad, we were sitting together and say, "OK, if they don't want to let us live like a family outside jail, we are living like a family in jail." And we go to the court, and say, "OK, we don't care. ...if you want to like,arrest us, ...it doesn't matter for us." Actually, [staying home] is the same [as staying in jail]. ...we have Palestine, we have land. But everyone is living in jail. ...We say we don't want to leave our houses. If you want, arrest all the family. We don't care (EJ1).

Sanaa's words indicate that home can be represented in contradictory ways. Even though Sanaa acknowledged that living in home is like a prison, she equates this as better than losing her home.

\section{Discussion and Conclusions}

Place is full of meaning, and the place called home - whether a castle or a cage - is one of the most meaningful places of all. The research findings illustrate that home can have deeply conflicting meanings to participants. This multiplicity and diversity is itself meaningful. Home is therefore not an individual feeling, but a plural and layered sentiment that travels from the home to the neighborhood community to the nationstate (Duyvendak 2011).

As the findings indicate, home can be a castle representing positive elements in children and families' lives, providing elements of family centeredness and protection. At the same time, home can also be a cage, an unstable and unhealthy place due to poverty, violence, and/or the overarching occupation. Many parents explained that they force their children to stay inside the home as a means of protection. Indeed, children are often constrained within the frames set by their caregivers. The dual (and often conflicting) needs for connection to and independence from person and place are a central theme in children's developmental histories. As children grow, they struggle to find a delicate balance between a profound dependence on primary caregivers and the need for independence. The above findings do not intend to emphasize that children's lives are controlled by their parents, but rather how children experience these constraints and the impact on their well-being. The description of the home can be looked upon as a way to explore the distinction between the inside safety of home and the outside danger associated with the violence of conflict as well as the conceptualization of home as a cage and a castle. Furthermore, Israel's spatial control and management of family life in Palestine consistently blurs the distinction between public and private spaces, thus compromising children's social interactions. Despite family members' range of feelings about home being a castle or a cage, attachment to home was still strong. For example, there were conflicting views of the home as a place of imprisonment, yet the same participant would later wholly defend their home as being extremely important.

\section{Limitations and Recommendations for Future Research}

This research used collaborative family interviews, which are a new method of data collection. The inclusion of the hamula in the research methodology provided a complex portrait of family experience. Interviewing the whole family - both children and adults together - had the potential to create a context of unequal power relations. Yet including the whole family in the research process helped uncover valuable data with regards to the importance and messiness of family interactions and generational differences in perceptions. At times, children's voices were indeed obscured by the voices of their older family members. However, inclusion of other research methods (drawing and mapmaking) made efforts to encourage children's participation. Overall, the inherent limitations that come with collaborative family interviews were avoided through the use of a combination of research methods that collected data from a variety of sources (e.g., parents, children, relatives, and community members) using a variety of methods (e.g., narrative drawing and mapmaking).

Future research should continue to explore collaborative family interviews as a method of data collection. In order to avoid potential groupthink that may result from a family interview, it is suggested that this method be combined with individual interviews with family members at the conclusion of the family interview. In this way, the family interview can be used as a means to develop trust, observe family interactions, and provide a sense of the areas to explore in individual interviews. Individual interviews would allow the researcher 
to explore issues with more breadth and depth than one family interview allows.

\section{Implications for Practice and Policy}

The place of family and home weave in and out of the everyday lives of children, impacting one another in diverse ways. Focusing on the home creates more intimate knowledge of family practices and the social environment that the child lives in. Belonging to a place - and by extension, belonging to a family and community - is part of the process of creating a sense of security and well-being for children. Yet, when that place is threatened, well-being may be compromised.

Listening to Children and Families Affected by Political Violence This research began by critically examining the concept and meaning of place in the lives of Palestinian children and families. But it ends with the need to take a moment to listen to the powerful narratives of children and families affected by political violence. Through their voices and production of visual materials, Palestinian children and families eloquently conveyed their perceptions, beliefs, and attitudes towards living in highly contested and violent place. They expressed both current struggles, while also conveying a sense of resilience and tempered hope. While retelling stories has the potential to retraumatize, children and families' narratives can also be viewed as a therapeutic means of being heard. Encouraging families to talk about their homes recognizes their everyday circumstances and provides comfort that someone is listening and they are participating in an alternative making of the history of conflict.

Challenging Human Rights Violations According to the United Nation's Convention on the Rights of the Child (1989), children have a right to good housing. Therefore, an unsafe home environment - whether due to poverty or political violence - should be reframed as a violation of children's rights. Additionally, considering the above research, restricted access to places outside the home - which turns a home into a cage as opposed to a castle - should also be considered as a violation of children's well-being in the context of political violence. Family narratives can therefore be used to challenge these human rights violations. The act of documenting these narratives can provide a valuable record of the importance of place in the lives of children and families. Documenting the experience that children and families have with their homes can provide evidence by which to challenge human rights violations.

Understanding Multiple Meanings of Home How can practitioners and policymakers reinforce the positive aspects of home that make children and families feel safe and secure in the midst of instability? As this study shows, family members may hold different meanings of home, which can be positive, negative, or both. Practitioners and policymakers working with children and families in these contexts should consider these diverse - and sometimes contradictory - meanings of home. Though home is often viewed as protective - and treated as such in practice and policies with populations affected by political conflict - it may also be a negative environment. Therefore, practice and policy must include diverse and unique experiences of home. Practitioners must allow for children and families to tell their own stories of home and what meaning - positive, negative, or both - they may attribute to home. Based on children and families own conceptualizations of home, policies should be developed that encourage the positive elements of home - gathering families together in the home, nurturing of one's identity based on home, and using the home as a protective physical space - and address the negative elements of home-ensuring that homes are physically healthy, increasing the privacy of homes that are in overcrowded environments, and providing opportunities for children and families to safely explore the places beyond their homes, thereby contributing to children and families well-being in the context of political violence.

\section{References}

Abujidi, N. (2005). Forced to forget: cultural identity and collective memory/urbicide. The case of the Palestinian territories, during Israeli invasions to Nablus Historic Center 2002-2005. Presented at the "Urbicide: The Killing of Cities?" Conference. Durham: Durham University.

Ahmed, S. (1999). Home and away: narratives of migration and estrangement. International Journal of Cultural Studies, 2(3), 329-347.

Allan, G., \& Crow, G. (1989). Introduction. In G. Allan \& G. Crow (Eds.), Home and family: creating the domestic sphere (pp. 1-13). Houndmills: Macmillan Press.

Altman, I. (1975). The environment and social behavior: privacy, personal space, territory, crowding. Monterey, CA: Brooks.

Altman, I., \& Chemers, M. M. (1980). Culture and environment. Monterey, CA: Brooks.

Araj, B. (2012). The motivations of Palestinian suicide bombers in the second intifada (2000 to 2005). Canadian Review of Sociology/ Revue Canadienne de Sociologie, 49(3), 211-232. doi:10.1111/j. 1755-618X.2012.01292.x.

B’Tselem. (2013). Statistics: fatalities. http://www.btselem.org/statistics/ fatalities/any/by-date-of-death. Accessed 1 Sept 2013

Baltzer, A. (2007). Witness in Palestine: a Jewish American woman in the occupied territories. Boulder, CO: Paradigm.

Birdwell-Pheasant, D., \& Lawrence-Zúñiga, D. (1999). House life: space, place, and family in Europe. Oxford: Berg.

Bleibleh, S. (2010). Everyday urbanism between public space and "forbidden space": the case of the old city of Nablus, Palestine (In: The Proceedings of spaces of history/histories of space: emerging approaches to the study of the built environment). California: University of California Berkeley. 
Brannen, J., \& O’Brien, M. (1996). Introduction. In J. Brannen \& M. O'Brien (Eds.), Children in families: research and policy. London: Falmer Press.

Brolin, B. C. (1976). The failure of modern architecture. New York, NY: Van Nostrand Reinhold Co.

Brym, R. J., \& Araj, B. (2006). Suicide bombing as strategy and interaction: the case of the second intifada. Social Forces, 84(4), 1969 1986.

Charmaz, K. (2006). Constructing grounded theory: a practical guide through qualitative analysis. London: Sage.

Christensen, P., \& O'Brien, M. (2003). Children in the city: introducing new perspectives. In P. Christensen \& M. O'Brien (Eds.), Children in the city: home, neighbourhood and community (pp. 1-12). London: Routledge Falmer.

Christensen, P., James, A., \& Jenks, C. (2000). Home and movement: children constructing "family time. In S. L. Holloway \& G. Valentine (Eds.), Children's geographies: playing, living, learning (pp. 139-155). London: Routledge.

Clark, A. (2004). The Mosaic approach and research with young children. In V. Lewis, M. Kellett, C. Robinson, S. Fraser, \& S. Ding (Eds.), The reality of research with children and young people (pp. 142156). London: Sage.

David, T. G., \& Weinstein, C. S. (1987). The built environment and children's development. In C. S. Weinstein \& T. G. David (Eds.), Spaces for children: the built environment and child development (pp. 3-18). New York, NY: Plenum Press.

Defence for Children International (DCI). (2010). Under attack: settler violence against Palestinian children in the occupied Palestinian territory [UPDATE]. Jerusalem: DCI.

Defence for Children International (DCI). (2012). Bound, blindfolded, and convicted: children held in military detention. Ramallah, Palestine: DCI-Palestine Section. http://www.dci-palestine.org/ documents/bound-blindfolded-and-convicted-children-heldmilitary-detention-2012.

Dennis, S. F., Gaulocher, S., Carpiano, R. M., \& Brown, D. (2009). Participatory photo mapping (PPM): exploring an integrated method for health and place research with young people. Health \& Place, 15(2), 466-473. doi:10.1016/j.healthplace.2008.08.004.

Douglas, M. (1991). The idea of home: a kind of space. Social Research, $58(1), 287-307$.

Duyvendak, J. W. (2011). The politics of home: belonging and nostalgia in Western Europe and the United States. Basingstoke, UK: Palgrave.

Easthope, H. (2004). A place called home. Housing, Theory and Society, 21(3), 128-138.

Edwards, R. (1998). A critical examination of the use of interpreters in the qualitative research process. Journal of Ethnic and Migration Studies, 24, 197-208.

Epshtain, I. (2012). Demolishing homes, demolishing peace. Jerusalem: Israeli Committee Against House Demolition (ICAHD).

Evans, G. W. (2006). Child development and the physical environment. Annual Review of Psychology, 57, 423-451.

Evans, G. W., \& Hygge, S. (2007). Noise and performance in children and adults. In L. Luxon \& D. Prasher (Eds.), Noise and its effects (pp. 549-566). London: Wiley.

Evans, G. W., \& Lepore, S. J. (1993). Nonauditory effects of noise on children: a critical review. Children's Environments, 10(1), 31-51.

Garbarino, J., \& Kostelny, K. (1996). The effects of political violence on Palestinian children's behavior problems: a risk accumulation model. Child Development, 67, 33-45.

Ghabra, S. (1988). Palestinians in Kuwait: the family and the politics of survival. Journal of Palestine Studies, 17(2), 62-83.

Glaser, B. G., \& Strauss, A. L. (1967). The discovery of grounded theory: strategies for qualitative research. Chicago: Aldine.

Gordon, N. (2008). Israel's occupation. Berkeley: University of California Press.
Guardo, C. J. (1969). Personal space in children. Child Development, 40(1), 143-151.

Hajjar, L. (2005). Courting conflict: the Israeli military court system in the West Bank and Gaza. London, UK: University of California Press.

Handwerker, W. P. (2001). Quick ethnography. Walnut Creek, CA: AltaMira Press.

Harker, C. (2011). Geopolitics and family in Palestine. Geoforum, 42(3), 306-315. doi:10.1016/j.geoforum.2010.06.007.

Hider, J. (2012). Israel "turning blind eye" to West Bank settlers' attacks on Palestinians. London, UK: The Guardian.

Institute for Counter-Terrorism (ICT). (n.d.). An engineered tragedy: statistical analysis of fatalities (Statistical Report Summary). Israel: Institute for Counter-Terrorism (ICT). http://www.ict.org.il/.

Jack, G. (2008). Place matters: the significance of place attachments for children's well-being. British Journal of Social Work, 40(3), 755771. doi:10.1093/bjsw/bcn142.

Jones, R. (2012). Border walls: security and the war on terror in the United States, India, and Israel. London, UK: Zed Books.

Khamis, V. (2000). Child psychological maltreatment in Palestinian families. Child Abuse \& Neglect, 24, 1047-59.

Krouzman, R. (1999). Twenty-first century Palestine: toward a swisscheese state? Middle East Report, 29.

Lang, J. (1987). Creating architectural theory: the role of the behavioral sciences in environmental design. New York, NY: Reinhold.

Lloyd, R., Patton, D., \& Cammack, R. (1996). Basic-level geographic categories. The Professional Geographer, 48(2), 181. doi:10.1111/j. 0033-0124.1996.00181.x.

Low, S. (2004). Behind the gates: life, security, and the pursuit of happiness in fortress America. New York, NY: Routledge.

Maykut, P., \& Morehouse, R. (1994). Qualitative data analysis: using the constant comparative method. In P. Maykut \& R. Morehouse (Eds.), Beginning qualitative research: a philosophic and practical guide (pp. 126-149). New York, NY: Falmer Press.

Meisels, M., \& Guardo, C. J. (1969). Development of personal space schemata. Child Development, 40(4), 1167-1178.

Mignone, J., Hiremath, G. M., Sabnis, V., Laxmi, J., Halli, S., O’Neil, J., \& Moses, S. (2009). Use of rapid ethnographic methodology to develop a village-level rapid assessment tool predictive of HIV infection in rural India. International Journal of Qualitative Methods, 8(3), 68-83.

Millen, D. R. (2000). Rapid ethnography: time deepening strategies for HCI field research. In Proceedings of the 3rd Conference on Designing Interactive Systems: processes, practices, methods, and techniques (pp. 280-286). New York, NY: ACM. doi:10.1145/ 347642.347763.

Moghadam, A. (2003). Palestinian suicide terrorism in the second intifada: motivations and organizational aspects. Studies in Conflict \& Terrorism, 26(2), 65-92. doi:10.1080/10576100390145215.

Morgan, D. H. J. (1996). Family connections: an introduction to family studies. Cambridge, UK: Blackwell.

Morgan, D. H. J. (1999). Risk and family practices: accounting for change and fluidity in family life. In E. Silva \& C. Smart (Eds.), The new family? (pp. 13-30). London, UK: Sage.

Mumford, L. (1961). The city in history: Its origins, its transformations, and its prospects. New York, NY: Harcourt, Brace \& World.

Murray, C. D., \& Wynne, J. (2001). Researching community, work and family with an interpreter. Community, Work, Family, 4, 158-171.

Nowicka, M. (2007). Mobile locations: construction of home in a group of mobile transnational professionals. Global Networks, 7(1), 6986.

Olds, A. R. (1987). Designing settings for infants and toddlers. In C. S. Weinstein \& T. G. David (Eds.), Spaces for children: the built environment and child development (pp. 117-138). New York, NY: Plenum Press. 
Panter-Brick, C., Goodman, A., Tol, W., \& Eggerman, M. (2011). Mental health and childhood adversities: a longitudinal study in Kabul, Afghanistan. Journal of the American Academy of Child and Adolescent Psychiatry, 50(4), 349-363. doi:10.1016/j.jaac.2010.12.001.

Parton, N. (2006). Safeguarding childhood: early intervention and surveillance in a late modern society. New York, NY: Palgrave Macmillan.

Peteet, J. (2005). Landscape of hope and despair: Palestinian refugee camps. Philadelphia, PA: University of Pennsylvania Press.

Porteous, J. D. (1976). Home: the territorial core. Geographical Review, 66(4), 383-390. doi:10.2307/213649.

Porteous, J. D., \& Smith, S. E. (2001). Domicide: the global destruction of home. Montreal, QC: McGill-Queen's University Press.

Pressman, J. (2003). The second intifada: background and causes of the Israeli-Palestinian conflict. Journal of Conflict Studies, 23(2). http:// journals.hil.unb.ca/index.php/JCS/article/view/220.

Rapoport, A. (1969). House form and culture. Englewood Cliffs, NJ: Prentice-Hall.

Relph, E. (1993). Modernity and the reclamation of place. In D. Seamon (Ed.), Dwelling, seeing, and designing: toward a phenomenological ecology (pp. 25-40). New York, NY: State University of New York Press.

Save the Children UK (SCUK), \& Palestinian Counseling Centre, \& Welfare Association. (2009). Broken homes: addressing the impact of house demolitions on Palestinian children and families. Jerusalem: Save the Children UK (SCUK) and Palestinian Counseling Centre, \& Welfare Association.

Spencer, C. (2005). Place attachment, place identity and the development of the child's self-identity: searching the literature to develop a hypothesis. International Research in Geographical and Environmental Education, 14(4), 305-309.

United Nations. (1989). Convention on the rights of the child. New York, NY: United Nations.

United Nations Office for the Coordination of Humanitarian Affairs (UNOCHA). (2007). The humanitarian impact on Palestinians of Israeli settlements and other infrastructure in the West Bank.

Wadi Hilweh Information Center-Silwan. (2013, September 12). AlSharabati family removes the tin plates from the roof of their house to avoid evacuation. Silwanic.net. Silwan, Jerusalem. http:// silwanic.net/?p=40416.

Weizman, E. (2007). Hollow land: Israel's architecture of occupation. London: Verso.

Wessells, M., \& Kostelny, K. (2004). A preliminary study of qualitative measures of Afghan children's coping strategies. Richmond, VA: CCF International.

Wolfe, M. (1978). Childhood and privacy. In I. Altman \& J. F. Wohlwill (Eds.), Children and the environment. New York, NY: Plenum Press. 